\title{
TADEJA TOPOLNIK
}

\section{BREZNIKOVO POJMOVANJE JEZIKOVNIH SPREMEMB V EVANGELIJIH IN LISTIH}

CoBISS: 1.01

Razpravo o literarni tradiciji v Evangelijih in listih (EiL) Antona Breznika razčlenjujemo z vidika avtorjeve metodologije raziskovanja. Na začetku razčlenjujemo Breznikovo razumevanje pojma literarna tradicija in preverjamo nekatere Breznikove trditve o razvoju slovenskega knjižnega jezika oz. jezikovnega sloga v EiL. V nadaljevanju opazujemo, kako se kažejo jezikovnoideološke poteze $\mathrm{v}$ njegovih opredelitvah besed in presoji različnih avtorjev EiL, razmišljamo o kvantitativni obdelavi podatkov, pomenu ter časovnem opredeljevanju jezikovne inovacije. Na koncu predstavljamo spremembe različnih zvez glagola s prislovom v enajstih izdajah EiL iz let 1612-2003.

Ključne besede: slovenščina, zgodovina jezika, jezikovne spremembe

\section{Anton Breznik's conceptualization of linguistic changes in Evangeliji in listi (Grospels and Epistles)}

This article uses a research methodology to analyze Anton Breznik's commentary on the literary tradition in the collection known as Evangeliji in listi (EiL, Gospels and Epistles). The article starts by analyzing Breznik's interpretation of the concept of literary tradition and some of his statements about the development of standard Slovenian, and literary style in EiL is also examined. It is then observed how linguistic ideology affects Breznik's definitions and the judgement of various authors in EiL. Quantitative data analysis and the definition of the meaning and the time of a linguistic innovation is also examined. Finally, changes in various verb-adverb combinations in eleven editions of EiL (from 1612 to 2003) are examined.

Keywords: Slovenian, language history, language changes

\section{UVOD}

»Vsak vidi zgodovino knjižnega jezika drugače, kakor jo je videl rod pred njim, v drugih okoliščinah. In zaradi teh drugih okoliščin je potrebno, da vsak rod raziskuje naprej. Kajti zgodovina ni nikdar raziskana za vse večne čase.« (Pogorelec 2011: 16)

Novi rodovi jezikoslovcev lahko, ko se ponovno lotevajo istih tem ali avtorjev kot njihovi predhodniki, vnašajo $v$ jezikoslovje nove ideje in $\mathrm{s}$ tem nadgradijo prizadevanja svojih predhodnikov ter s svojim delom postavljajo naslednikom izhodišča za nove refleksije.

$\mathrm{V}$ tem prispevku predstavljam Breznikovo raziskovanje in pojmovanje literarne tradicije v Evangelijih in listih (v nadaljevanju EiL) z metodološkega vidika. Povod za temeljitejšo analizo Breznikove razprave Literarna tradicija v Evangelijih in listih (Breznik 1982) je raziskovanje istega vira, to so besedila različnih 
izdaj EiL.1 Na prvi pogled se zdi, da je ena izmed Breznikovih najbolj odmevnih jezikoslovnih razprav, ki jo je napisal leta 1908 pri svojih 27 letih, Besedni red v govoru (Breznik 1982), saj je s svojo temo sprožila odziv številnih jezikoslovcev (Toporišič 1982; Vidovič Muha 1994; 2006; 2008; Škrabec 1994-1998; Skubic 1997/98; Zuljan Kumar 2008), njegova jezikovnozgodovinska razprava Literarna tradicija v Evangelijih in listih (prvič izšla 1917) pa pri slovenskih ali tujih jezikoslovcih ni bila deležna tako velike pozornosti. Doslej se ni še nihče ukvarjal z vprašanji Breznikove metodologije ali metodologije jezikoslovcev 19. stoletja tako, da bi podrobneje analiziral tehniko ali postopke, s pomočjo katerih so jezikoslovci prišli do podatkov, ali na kakšen način so zbrali gradivo in na podlagi dobljenih informacij oblikovali svoje znanstvene ugotovitve.

Martina Orožen (2002) sicer z različnimi teoretičnimi in metodološkimi pristopi prikazuje, kako različni jezikoslovci v treh različno naravnanih, a dopolnjujočih se obdobjih v 19. stoletju vsak na svoj način odkrivajo strukturno identiteto slovenskega knjižnega jezika. V prvem, Kopitarjevem filološkem obdobju (1808-1848) ob soočanju knjižnih deželnih različic $z$ »ljudskim jezikom« na vseh jezikovnih ravninah ločujejo jezikovne prvine na izvirne in neizvirne ter neizvirne izločajo. 2 V drugem, Miklošičevem genetično-primerjalnem obdobju (18481880) so dosegli dogovor o enotni knjižni normi, vendar je strukturna identiteta slovenskega jezika vezana na soočanje s »staroslovenščino« in slovanskimi jeziki. V tretjem, Škrabec-Oblakovem mladogramatičnem obdobju (1880-1918) se raziskovalci ukvarjajo pretežno z raziskovanjem glasoslovno-oblikoslovnih ravnin in jezikovnih prvin, pri čemer jih zanima njihov razvojni potek do sodobnega stanja ter postane predmet njihovega zanimanja tudi govorjeni in ne le zapisani knjižni jezik. Raziskovalci si prizadevajo za popolno zajetje, ustrezen opis, razlago in knjižno normiranje jezikovnih prvin.

Pri odkrivanju strukturne identitete slovenskega knjižnega jezika moramo upoštevati tudi sociolingvistične vidike, ki so posredno ali neposredno vplivali na različne teoretične in metodološke pristope v omenjenih treh obdobjih.

Sociolingvistične vidike lahko opredelimo v povezavi z jezikovnim načrtovanjem, natančneje s številnimi normativističnimi postopki, kot so izbira norme

1 V pilotni raziskavi za empirični del svoje doktorske disertacije, v kateri proučujem sinhrone in diahrone dejavnike stabilnosti besedja slovenskega knjižnega jezika, sem pregledala enajst različnih izdaj EiL, in sicer po letih: $1612 \rightarrow$ Hren 1612; $1672 \rightarrow$ Schönleben 1672; $1730 \rightarrow$ Hipolit 1730; $1777 \rightarrow$ Pohlin 1777; $1780 \rightarrow$ Küzmič 1780; 1787 $\rightarrow$ Japelj 1787; $1809 \rightarrow$ Japelj $1809 ; 1816 \rightarrow$ Ravnikar 1816; $1833 \rightarrow$ Burgar 1833; $1840 \rightarrow$ EiL 1840; $1912 \rightarrow$ Lesar 1912; 2003 , ter izpisala spremenjene besede in besedne zveze. Z EiL okrajšujem vsa dela tega tipa, čeprav je v naslovu drugačno zaporedje ali branje. - Naredila sem izpise v temle obsegu: Hren 1612 do str. 110; Schönleben 1672 do str. 214; Hipolit 1730 do str. 189; Pohlin 1777 do str. 174; Küzmič 1780 do str. 62; Japelj 1787 do str. 166; Japelj 1809 do str. 171; Ravnikar 1816 do str. 111 in Burgar 1833 do str. 299.

2 Na iskanje omenjenih prvin vplivajo tudi različne filozofske smernice, ki so vplivale tako na pogled na jezik kot tudi na način, obseg, namen in metode dela v jezikoslovju (Orožen 2002: 220). 
(selekcija), opisovanje (deskripcija), predpisovanje (kodifikacija), razvijanje (elaborizacija), sprejemanje (akceptiranje), uveljavljanje (implementacija), širitev (ekspanzija), gojitev (kultiviranje), vrednotenje (evalvacija) in preurejanje (rekonstrukcija), katerih uresničenost vodi k dosegi zrelega knjižnega (standardnega) jezika (Dular 1988: 31, 32).

Uresničevanje omenjenih postopkov je bilo $\mathrm{v}$ slovenskem prostoru odvisno od specifičnih družbeno-političnih razmer ter zemljepisnih in demografskih značilnosti slovenske jezikovne skupnosti, ki so delovale na poseben razvoj identitete slovenskega jezika in naroda. Jezikoslovna dela omenjenih treh obdobij so nastala $\mathrm{v}$ obdobju, zaznamovanem s filološko znanstveno metodo, ki je odločilno vplivala tudi na način jezikoslovnega raziskovanja in interpretiranja ugotovitev slovenskih jezikoslovcev, to je historizem.

Za navedeno klasično metodo, ki je prevladovala v 19. in velikem delu 20. stoletja, je značilen zgodovinski, diahroni pristop $\mathrm{k}$ jeziku in jezikoslovnim pojavom, raziskovanje starejših jezikovnih stanj, jezikovnih sorodnosti, etimološke študije, vse to za lažje normiranje in vzpostavljanje kontinuitete slovenskega knjižnega jezika (Orel 2002: 201).3

Standardizirani knjižni jezik se je v drugi polovici 19. stoletja oblikoval pod vplivom dveh jezikovnoideoloških načel: pristnega govora slovenskega ljudstva in preverjenega zgodovinskega rodovnika jezikovnih izrazil. Slednje načelo se je še bolj okrepilo z razvojem primerjalno (slovanskega in indoevropskega) jezikoslovja (Stabej 2012: 17; Urbančič 1963: 213; Pogorelec 1962: 1594).

Med prvimi znanstvenimi metodami jezikoslovnega raziskovanja $\mathrm{v}$ prvi polovici 20. stoletja se je pojavil strukturalizem, ki je postavljal v ospredje sinhroni opis, strukturo in delovanje jezikov ter ločeval sinhronijo in diahronijo (Bernard 2002: 9, 10). Znotraj strukturalizma se pojavlja funkcionalizem kot element, ki opredeljuje praški strukturalizem in vpliva na slovenske jezikoslovce (Vidovič Muha 2000: 276).

"Samo sinhrono stanje jezika lahko zagotavlja analitiku zaključene in popolno kontrolirane materiale, « je eden izmed Mathesiusovih zaključkov (Mathesius po Vachek 1966: 20), pri čemer se moramo zavedati, da čeprav Mathesiusa označujejo kot strukturalista in funkcionalista, to ne pomeni, da tako on kot drugi predstavniki praškega lingvističnega kroga niso posvečali pozornosti diahronim problemom ali da so jih celo ignorirali. Mathesius se je zavedal prednosti in pomanjkljivosti obeh pristopov in skušal s sintezo obeh pristopov priti do zaključkov (Vachek 1966: 17, 20).

Breda Pogorelec je ob izidu Slovenskega pravopisa 1962 kritično ovrednotila delo pravopisne komisije, tako da je sicer priznavala pomen zgodovinskega načela, toda hkrati opozorila, da jezikoslovcu metodo narekujeta tudi namen in stanje

3 Vpliv historizma v oblikoslovnih opisih 19. in 20. stoletja je raziskovala Irena Orel (2002).

4 Različni avtorji različno opisujejo načelo; tako Breda Pogorelec govori o »zgodovinskem principu izvora in »ljudskosti in domačijskosti jezikovnega pojava, oblike ali izraza« (Pogorelec 1963: 159), navaja tudi »ljudski govor, ljudski jezik« (Pogorelec $1963: 160)$, Urbančič pa govori o »načelu historične pravilnosti/zgodovinske upravičenosti« (Urbančič 1963: 213). 
jezikoslovja v sodobnem svetu. Sestavljavci pravopisa naj bi pri svojem delu s sodobnimi jezikoslovnimi metodami reševali jezikoslovne probleme, upoštevali dejansko rabo v knjižnem jeziku in vse starostne plasti, ki knjižni jezik uporabljajo, ter zakonitosti različnih tekstov, za katere pripravljajo pravopis. Govori o t. i. kriteriju sodobnega (Pogorelec 1962: 161-168).

Urbančič izpostavlja komunikacijsko vlogo jezika, zaradi katere je zanj pomembnejša tendenca (ki jo je treba upoštevati kot pravopisno načelo) ustaljenost jezikovnih sredstev kot pa etimološko in historično načelo (Urbančič 1963: 212, 213, 218).

Tako tujim kot slovenskim jezikoslovcem je skupno osredotočanje bodisi na sinhronijo (sočasnost) bodisi na diahronijo (raznočasnost) v jezikoslovnih raziskovanjih, čeprav ne zanikajo obstoja drugega raziskovalnega načela. Verjetno bi bilo optimalno, da bi vsak jezikoslovec pri svojem delu skušal v ustreznem sorazmerju zadostiti obema meriloma (zgodovinskemu in sodobnemu).

\section{POJEM LITERARNA TRADICIJA V BREZNIKOVI RAZPRAVI}

Breznik pojem literarna tradicija razume drugače, kot si ga razlagamo danes. Pojem literatura, literaren v sodobnem jeziku povezujemo s književnostjo, umetnostnimi besedili in umetnostnim jezikom, 5 medtem ko Breznik besedno zvezo literarna tradicija pojmuje kot vso (reprezentativno) besedilno produkcijo v knjižnem jeziku. Ugotoviti skuša, kaj se je skozi različne izdaje EiL ohranjalo in ohranilo, kaj izkazuje kontinuiteto v jeziku EiL, primerja torej, kako se je skozi različne izdaje spreminjala jezikovna podoba besedila in v kolikšni meri so pisci EiL upoštevali različne prevode Svetega pisma, in sicer grški izvirnik, Vulgato in druge vire. Breznik v svojih razpravah posredno izkazuje predstavo o jeziku, ki se skozi zgodovinski razvoj na vseh ravninah razvija v čedalje bolj urejen jezik.

Namesto Breznikovega pojma literarna tradicija Dular uporablja izraz prožna stanovitnost, ki ga opredeljuje kot stanje knjižne slovenščine v zgodovinskem razvoju, ki skupaj z množično potrjevanostjo knjižne slovenščine v besedilih zmanjša nujnost kodifikacijskega postopka predpisovanja njene norme in poveča potrebo po drugem kodifikacijskem postopku, in sicer opisu njene slovnične in slovarske sestave ter slogovne razplastenosti (Dular 1988: 33).

Mathesius se kritično opredeljuje do stališč praških lingvistov, ko poudarja pomen neločljivosti sinhronega in diahronega raziskovanja, in za označevanje pravkar opisane značilnosti besedil uporablja pojem »prožna stabilnost ali ustaljenost, 6 tj. nenehno stanje počasnega vstopanja novih in izstopanja zastarelih jezikovnih sredstev« (Mathesius po Skubic 2005: 40). Mathesius omenja zahtevo po prožni stabilnosti kot glavno načelo jezikovnega sistema, pomembno za kulturo jezika. Opisal jo je kot predstavo o živosti na eni in o zastarelosti jezika na drugi strani (Mathesius 1932: 15).

$5 \quad$ Po SSKJ je literatura 'umetnost, ki ima za izrazno sredstvo besedo, jezik, književnost'.

6 Monika Kalin Golob uporablja pojem prožna ustaljenost (Kalin Golob 2008: 45, 46, 51). 


\section{BREZNIKOVE UGOTOVITVE Z DANAŠNJE PERSPEKTIVE}

V svoji raziskavi7 sem opazovala Breznikov metodologijo, s katero izvaja svoje sklepe glede jezikovne kvalitete prevodov posameznih izdaj in prevajalcev EiL ter razvoja slovenskega knjižnega jezika, »jezikovnega sloga«, kot temu pravi Breznik (1982: 33, 48), v EiL. Različne izdaje EiL primerja med seboj predvsem na podlagi analize besedja in skladenjskih pojavov. Prevajalce različnih izdaj EiL med seboj primerja in jih presoja, pri čemer je zanj najpomembnejše merilo vrednotenja vključevanje bolj ali manj slovenskih izrazov in »konstrukcij « (Breznik 1982: 29, 34, 39) namesto germanizmov.

Breznikove trditve sem primerjala s svojimi ugotovitvami in odkrila določena razhajanja $\mathrm{v}$ empiričnih raziskovalnih postopkih, $\mathrm{v}$ razmišljanju o jeziku in prevajalcih EiL,v merilih za presojanje prevajalcev in $\mathrm{v}$ časovnem opredeljevanju jezikovnih inovacij. Razlike so posledica številnih vzrokov; med pomembnejšimi so tisti metodološke in teoretske narave, saj se metodologija raziskovanja pod vplivom različnih, tudi sociolingvističnih dejavnikov vedno znova spreminja.

$\mathrm{S}$ primerjavo med Breznikovo in lastno pilotno raziskavo prihajam do naslednjih sklepov o Breznikovem metodološkem pristopu k analizi besedila EiL: (1) Breznik opredeljuje jezikoslovne pojave izrazito vrednotenjsko in (2) spremembe opredeljuje kvantitativno, ne da bi bilo popolnoma razvidno, na podlagi katerih empiričnih korakov je prišel do navedenih ugotovitev.

Poleg tega opažamo tudi, da so se nekatere jezikovne spremembe, ki jih Breznik pripisuje posamičnim avtorjem, zgodile že prej in da moramo biti pri sodobnem razumevanju nekaterih jezikoslovnih terminov, ki jih uporablja Breznik, previdni, saj lahko danes delujejo zavajajoče in vodijo k nesporazumom.

\subsection{Vrednotenjsko opredeljevanje}

V Breznikovi razpravi je opazno vrednotenjsko opredeljevanje jezikovnih izrazil, ko določeno kategorijo besed označi kot »pristne slovenske besede « (Breznik 1982: 34), »preproste besede« in »dobre slovenske izraze in konstrukcije « (Breznik 1982: 29), pa tudi opredeljevanje jezika posameznih prevajalcev EiL, ki ga označuje kot »najčistejšo slovenščino« (Breznik 1982: 35), »pristni narodni jezik « (Breznik 1982: 35) in »čisti besedni zaklad« (Breznik 1982: 41). Na tem in še na nekaterih drugih mestih Breznik v svoji terminologiji in v svojem presojanju z današnjega stališča izkazuje izrazito puristični in ideološko obarvani jezikovni nazor, perspektivo, ki v sodobnem jezikoslovju ni zaželena.

Odnos jezikoslovcev do purizma je bil $\mathrm{v}$ različnih obdobjih različen, odvisen od številnih med seboj prepletenih dejavnikov: stopnje razvoja standardiziranosti jezika; meril, na podlagi katerih se je iz jezika izločalo t. i. tuje prvine; politično-

7 Pri raziskavi v okviru mojega interdisciplinarnega humanističnega študija sta mi bila v veliko pomoč moj mentor Marko Stabej in somentor Kozma Ahačič. Za vse dragocene strokovne pripombe, komentarje in usmeritve sem jima iskreno zahvaljujem. 
-geografske ureditve slovenskega ozemlja in ekplicitno izraženega namena purizma, ki je vzpostavljanje narodne identitete Slovencev preko ohranjanja jezika in graditev njegove prestižne vloge.

»Prej ali slej se vsak kulturen jezik razvije do stopnje, ko mu postane purizem odveč in se ga začne otresati, prav tako kakor se vsaka družba prej ali slej otrese vseh oblik fanatične nestrpnosti, čeprav so jo morda pomagale graditi« (Bezlaj 2003: 776).

»V strahu pred germanizacijo so ilirci videli rešitev v politični enotnosti $\mathrm{s}$ Hrvati in jezikovnem zbližanju z njimi. Iz tega se je rodil bolni purizem naslednjih desetletij: mrzlično brskati za vsem, kar je v jeziku tujščine, pleti, puliti, ruvati. In s čim zadelati vrzeli? Seveda z besedami iz drugih slovanskih jezikov. Tako se je knjižni jezik čedalje bolj oddaljeval od ljudskega, postajal je papirnat.« (Bajec 1965: 204) $)^{\mathbf{8}}$

Jezikoslovje naj bi kot vsaka znanstvena veda temeljilo na teoriji, ki je zgrajena na objektivnih in preverljivih merilih in hipotezah, čeprav se moramo zavedati, da je tudi znanstvenost neke vrste ideologija in da tudi znanost ni nikoli popolnoma neodvisna od različnih družbenih ideologij in drugih vplivov (Stabej 2012: 12).

George Thomas purizem v širšem smislu označuje kot poskus zagotavljanja modela jezikovnih načel, ki temelji na predpostavki o sprejemljivosti ustaljenih jezikovnih elementov na podlagi njihovega izvora. Purizem ločuje jezikovne elementov glede na izvor: na nesprejemljive in sprejemljive elemente, do katerih nima nobenih predsodkov (Thomas 1997: 134).

Izraz purizem ni enoznačen pojem, saj ima lahko različne posledice za jezik in v različnih jezikovnih situacijah deluje različno. V primeru t. i. zmernega (pozitivnega, konstruktivnega) purizma je v ospredju purističnih prizadevanj skrb za ohranjanje jezika in njegovega prestiža, medtem ko skrajni (negativni, ksenofobični) purizem iz strahu pred ogroženostjo domačega jezika do tolikšne mere odklanja tujejezične prvine, da zavira jezikovni razvoj. Če hočemo ovrednotiti purizem, moramo poznati situacijo, v kateri se pojavlja. Delovanje purizma je tesno povezano $\mathrm{s}$ tremi vrstami situacij, in sicer $\mathrm{s}$ standardizacijo jezika, $\mathrm{z}$ jeziki v stiku in z jezikovnimi spremembami (z vidika stilnega registra in diglosije). (Kalin Golob 2008: 16, 17, 18)

$\mathrm{Na}$ Slovenskem se je v preteklosti pojavil zmerni (pozitivni, konstruktivni) purizem, ki je nastal hkrati z nastankom slovenskega knjižnega jezika in se je nadaljeval v obdobju protestantizma kot nazor, usmerjen proti germanizmom, ter se najbolj intenzivno izrazil pri Franu Levstiku, ki je nasprotoval germanizmom na različnih ravneh (skladnja, besedni red, besedotvorje). (Kalin Golob 2008: 19)

V preteklosti je bil omenjeni nazor precej uveljavljen, saj si je morala slovenščina $v$ 19. stoletju šele izboriti enakovreden položaj z drugimi jeziki in polno

$8 \quad$ Bajec na začetku razprave opredeljuje purizem kot pozitiven jezikoslovni pojav, ki naj bi se rodil sočasno z našo književnostjo (Bajec 1965: 203). 
funkcionalnost. Pri utrjevanju statusa in vloge slovenščine kot enakovrednega jezika v tedanji večjezični državni skupnosti sta pomembno vlogo odigrala jezikovno načrtovanje in jezikovna politika.

V razpravi Antona Breznika lahko med vrsticami razberemo še eno jezikovno ideološko potezo - težnjo na normativni ravni slediti jezikoslovcu vodniku, ki mu je dana avtoriteta, da presoja jezikovno pravilnost in ustreznost besedil.

Tako v Breznikovi razpravi najdemo številne izrazito ekspresivne oznake jezikovnih izrazil, na podlagi katerih vrednoti prevajalce EiL in njihove prevode. Breznikove oznake lahko razdelimo na tri skupine glede na tri merila, na podlagi katerih presoja kvaliteto prevoda in prevajalca: 1. raba germanizmov (na besedni ali skladenjski ravni), 2. upoštevanje tradicije (t. i. zgodovinsko načelo) in 3. prevodna predloga.

2.1.1 Prvo merilo, na podlagi katerega nekatere prevajalce in prevode opredeljuje kot bolj in druge kot manj ustrezne, je raba germanizmov. Tako $\mathrm{v}$ njegovi razpravi beremo:

- $\quad$ Dalmatin je namreč na mnogih mestih Trubarja poslabšal in mu zavrgel dobre slovenske izraze ali konstrukcije, [...]« (Breznik 1982: 29);

- $\quad \gg$ Res je Dalmatin znal besede in izraze na novo tvoriti in sestavljati, $v$ čemer je bil nešolani Trubar jako neokreten, in res je tudi nekatere Trubarjeve germanizme popravil [...], ali mnogo lepih izrazov in besed je tudi poslabšal, nadomestivši jih z germanizmi« (Breznik 1982: 30);

- $\quad$ ॥Žal, da Dalmatin ni znal tako svobodno uporabljati Trubarja, kakor sta storila Krelj in Jurišič, ki sta sprejela le dobre stvari, germanizme pa po večini odpravila« (Breznik 1982: 31);

- " - in tako smo v rabi časov, načinov, neslovenske trpne oblike, v rabi deležnikov, členkov, besednega reda itd. še sedaj odvisni od Dalmatina in od Lutrove nemščine, kar je za nekatere slovenske jezikovne pojave naravnost usodno, ker nemščina ni isto kar grščina, v kateri je sveto besedilo spisano« (Breznik 1982: 33);

- $\quad$ Veliki Ravnikar, ki je popolnoma reformiral slovenski jezikovni slog, je tudi Japljevim evangelijem in listom dal slovensko lice« (Breznik 1982: 33), »vendar pa so se zgodile vmes nekatere važne spremembe [namreč med izidom Dalmatinove in Hrenove izdaje - TT]: [...] 2. [Hren] je nadomestil mnogo nemških besed s pristnimi slovenskimi« (Breznik 1982: 33, 34);

- $\quad$ Hren je prvi, ki se je postavil na strogo slovensko stališče in je načelno zavračal vse, kar je v jeziku tujega. V tem oziru se ne more meriti z njim noben protestantski pisatelj, tudi Krelj in Juričič ne, dasi sta pisala med vsemi najčistejšo slovenščino.« (Breznik 1982: 34-35);

- $\quad$ Tako je cerkev po Hrenovi zaslugi veliko storila za čistočo božje besede« (Breznik 1982: 35);

- $\quad$ Vse, kar se je pozneje zgodilo glede čistoče našega besednega zaklada, je le nadaljevanje in dosledno izvajanje Hrenovega načela. Po tem načelu [mišljeno je Hrenovo slovensko stališče - TT] se je naš besedni zaklad $\mathrm{v}$ dobi romantike in ilirskega pokreta na podlagi pristnega narodnega jezika ter drugih slovanskih jezikov, zlasti hrvaščine in stare slovenščine, dvignil na tisto višino, na kateri stoji še danes. To načelo je zdravo, vendar se večkrat ni izvajalo v pravih merah. Nekateri ilirci so hoteli slovenščino preveč mešati z drugimi slovanskimi besedami, Levstik pa jo je hotel prepojiti še s staro slovenščino. A pismeni jezik je to počasi prebolel.« (Breznik 1982: 35);

- $\quad$ Protestantski pisatelji so bili glede tujk na ljudskem stališču: tujke, ki jih je govorilo ljudstvo, so sprejeli v knjigo, dasi so vedeli časih za dobre slovenske izraze. [...] Hren pa je z občudovanja vredno doslednostjo zavrgel vse, kar se mu je zdelo tuje.« (Breznik 1982: 35);

- $\quad$ Za tujko je smatral celo pristno slovensko besedo grob« (Breznik 1982: 35);

- $\quad$ Natančno pa se dá dokazati, da jih je vzel iz ,registra“ na koncu Biblie, kjer je bilo za tujke mnogo pristnih slovenskih in kajkavskih besed « (Breznik 1982: 36); 
- $\quad$ „Glede Hrena je treba posebej naglasiti, da se čistoča njegovega jezika nanaša samo na besedni zaklad, ne na ves jezik, tj. na skladnjo. Skladnja ni prav nič boljša od Dalmatinove.« (Breznik 1982: 37);

- $\quad$ Govoreč posebej o Schönlebnu, moram najprej omeniti, da se mu po krivici že od Kopitarjevega časa (1808) očita, da je pokvaril Hrenov čisti besedni zaklad.« (Breznik 1982: 41);

- $\quad$ Tako stoji Schönleben v tej stvari tako visoko kakor Hren sam. Pač pa je omahnil s te višine prireditelj izdaje iz leta 1730 (ali morebiti že prej o. Hipolit) in zavrgel kakih 15 slovenskih, po Hrenu uvedenih, besed in jih nadomestil s tujkami.« (Breznik 1982: 42);

- $\quad$ Kar je še bolj obžalovanja vredno, je pa to, da so se te tako ukoreninile, da je celo Japelj mislil, da ni mogoče več izhajati brez njih « (Breznik 1982: 42-43);

- »Poleg tega je tudi v jezikovnem oziru za Hrenom največ storil, ker je marsikak člen pri samostalnikih opustil, [Pohlin - TT] precej germanizmov iztrebil in marsikako domačo konstrukcijo uvedel.« (Breznik 1982: 46);

- $\quad »[\ldots]$ priredili novo izdajo Listov in evangelijev, kjer so te germanizme odpravili in jezik tudi v ostalem nekoliko zboljšali.« (Breznik 1982: 47);

- Ker sta Trubar in Dalmatin prevajala Lutra večinoma po črki, z vsemi podrobnostmi nemškega jezika, sta imela skoraj popolnoma nemško skladnjo« (Breznik 1982: 48);

- $\quad$ Nekoliko boljšo skladnjo so imeli poleg Krelja in Juričiča M. Kastelic, Janez Svetokriški in mestoma J. Basar. Najslabšo skladnjo so imeli pisatelji, ki so izdajali po večini prevode, kakor o. Hipolit, Paglovec, Rogerij idr. Veliko napredka še tudi pri Japlju ni opaziti, tako da zaostaja za svojim vrstnikom Linhartom. Nemške skladnje sta nas osvobodila šele Kopitar in Ravnikar, ki sta jezik tako izčistila, da so bili dani pogoji za velikega umetnika (Prešerna). Kopitarjeva slovnica (1808) je prvikrat pokazala slovenščino v luči drugih slovanskih jezikov in je odkrila mnogo germanizmov v tedanjem pismenem jeziku. Še bolj pa se je poglobil v bistvo slovenskega izraza Ravnikar, ki je svoje in Kopitarjeve rezultate prenesel v lepo književnost in prvič pokazal, kako se slovenski piše.«(Breznik 1982: 48);

- $\quad$ Najbolj žalostno pa je, da smo se svetopisemskih germanizmov in drugih pomanjkljivosti tako navadili, da se jih več ne zavedamo [...] In tak jezik piše vsak, celo najboljši stilisti, kakor Cankar, Finžgar, Meško in drugi.« (Breznik 1982: 54)

\subsubsection{Pri drugi skupini oznak Breznik opredeljuje določene prevajalce kot bolj ali manj} uspešne pri svojem delu na podlagi vzpostavljanja kontinuitete v jeziku, torej na bolj uspešne, ki upoštevajo tradicijo, in na drugi strani prevajalce, ki pomenijo odmik od tradicionalnega, zgodovinskega jezika ter vnašajo nove, lastne rešitve. Drugo merilo opažamo v sledečih navedbah:

- $\quad »$ Dalmatinovo besedilo se je od Hrena do Japlja (1787) [...] ohranilo še skoraj nedotaknjeno. [...] Resnične spremembe so se izvršile šele v Japljevi izdaji [...]. Vendar se tudi Japelj ni več kot približno za 50 \% osvobodil Dalmatina.« (Breznik 1982: 33);

- $\quad$ Vse izdaje do Ravnikarjeve (1816) so skoraj gol ponatisk Japljeve.« (Breznik 1982: 33);

- „Leta 1833 jih je stilistično in nekoliko frazeologično opilil Jož. Burgar, izboren stilist, znan somišljenik Metelkov« (Breznik 1982: 33);

- $\quad »[H r e n]$ je nekaj izrazov in konstrukcij popravil in vpeljal nekaj živih oblik in časih celó pravopis izboljšal, le nekatera mesta je poslabšal« (Breznik 1982: 34);

- $\quad$ (Vse nove tvorbe se mu [Hrenu - TT] niso enako posrečile in se zato niso vse udomačile« (Breznik 1982: 37);

- $\quad$ Tretjina jih pa živi še danes v najnovejši ljubljanski in lavantinski izdaji (1912), dasi bi bilo treba nekatere nadomestiti z boljšimi izrazi« (Breznik 1982: 37);

- $\quad$ Tretja Hrenova zasluga je, da je popravil nekatera mesta Dalmatinovega besedila v stvarnem oziru; spreminjal je večinoma le posamezne fraze, besede, konstrukcije, oblike itd.« (Breznik 1982: 39);

- $\quad$ Prvi, ki je skušal v njih pretrgati vso pismeno tradicijo in uvesti vanje svojo živo (ljubljansko) govorico, je bil Pohlin, a nevarnost za pisavo je tedaj že pri kraju, ker je kmalu za tem nastopil 
Japelj, ki se je zopet tesno oklenil Dalmatina, kar mu je štela v veliko zaslugo ne le romantika, ampak tudi moderno slovensko jezikoslovje (Škrabec)« (Breznik 1982: 41);

- $\quad$ Zamolčati pa ne smemo tega, da je Schönleben vse, kar ima dobrega, vzel po Hrenu« (Breznik 1982: 43);

- $\quad$ Besedilo je ostalo skoraj nespremenjeno (predrugačil je nekaj besed, a pri tem je marsikaj pokvaril [nanaša se na Paglovčevi izdaji iz let 1741 in 1764 - TT] « (Breznik 1982: 46);

- $\quad$ V pravopisnem oziru jih je jako zmrcvaril [nanaša se na Pohlinovi izdaji iz let 1772 in 1777 TT], ker je pretrgal skoraj vso pismeno tradicijo, a v stvarnem oziru jih je precej dvignil« (Breznik 1982: 46);

- $\quad$ Japelj sv. pisma ni na novo prevajal, temveč je v Dalmatinovem besedilu zboljšal le posamezne izraze, konstrukcije, fraze in posamezne stavke, podlaga je ostala Dalmatinova in to posebno v jezikovnoformalnem oziru« (Breznik 1982: 47);

- $\quad$ Vendar pa je mnogokrat preziral resnične poprave svojih prednikov, zlasti Pohlinove, ter je iznova prepisoval jezikovne in stvarne napake iz Dalmatina« (Breznik 1982: 47);

- $\quad$ "[...] mlajši sotrudniki (Vodnik, Debevc, Miklavčič itd.), ki so prevod v frazeologičnem oziru jako dvignili« (Breznik 1982: 47-48).

2.1.3 Pri tretji skupini oznak deli Breznik avtorje in njihova besedila glede na dve prevodni predlogi, to je glede na Vulgato in Lutrovo predlogo. V naslednjih oznakah navaja svoje ugotovitve o tem, kateri izmed obeh predlog so sledili posamezni avtorji pri prevajanju:

- «Navzlic germanizirajočemu slogu pa sta Trubar in Dalmatin ustvarila dobre prevode in sta $\mathrm{v}$ primeri s poznejšimi prevajalci, s Hrenom, Schönlebnom, Japljem, Wolfom itd., prava velikana« (Breznik 1982: 31);

- $\quad$ Hren je res veliko večino Dalmatinovega besedila z diplomatično natančnostjo prepisal [...], vendar pa so se zgodile vmes nekatere važne spremembe: 1 . je spremenil nekaj mest, ki se niso ujemala z vulgato« (Breznik 1982: 33);

- $\quad$ Ker je Dalmatin prevajal po Lutru in ta po grškem - Luter je prevajal precej vestno, le tu pa tam je kako mesto tolmačil subjektivno, po svojem protestantskem načelu -, je hotel imeti Hren natančno besedilo po vulgati« (Breznik 1982: 34);

- $\quad$ »Tu pa tam je celó slovenske besede ,tvoril‘ po vulgati. Mnogo mest je pa tudi spregledal, utrudil se je posebno proti koncu knjige« (Breznik 1982: 34);

- $\quad$ Od Japlja dalje pa besedila niso več imeli na sumu, misleč, da je strogo vulgatsko, in so ga le malo kontrolirali« (Breznik 1982: 34);

- »Primerjal je [Jožef Burgar - TT] prevod tudi precej vestno z vulgatskim besedilom; [...] pozneje ni te lutrovščine nihče več trebil iz slovenskega prevoda« (Breznik 1982: 52).

Breznik svoj jezikovni nazor gradi tudi na izrazitem poveličevanju nekaterih avtorjev, in sicer v največji meri Hrena in Ravnikarja; označil ga je kot »velikega reformatorja našega jezika« (Breznik 1982: 30), ki je »prvič pokazal, kako se slovensko piše« (Breznik 1982: 48). Mogoče je vzrok tako velikega navdušenja nad obema jezikoslovcema tudi svetovnonazorska bližina vseh treh, saj so bili vsi trije duhovniki in so deklarativno zagovarjali načelo, da mora literarni jezik temeljiti na ljudskem jeziku. Breznik zagovarja stališče, ki je bilo skupno stališče pretežnega dela slovenskih jezikoslovcev v 19. stoletju, da se ljudski jezik, ki ga govori ljudstvo v narečjih, bolj naravno razvija ter vsebuje stare pojave iz praslovanščine, medtem ko se knjižni jezik razvija pod tujim vplivom in vplivom pisateljev, ki ga oblikujejo samovoljno. »Koliko domačih izrazov živi še 
med ljudstvom, medtem ko izobraženci in pismeni jezik rabijo tujke! « (Breznik 1982: 384) Podobna razmišljanja najdemo tudi pri jezikoslovcih 20. stoletja. Že Kopitar je poudarjal, da je knjižni jezik treba spremeniti tako, da se opremo na ljudski jezik ter besede tujega izvora zaradi večje razumljivosti nadomestimo $\mathrm{z}$ besedjem ljudskega jezika in besedjem iz »drugih slovanskih narečij«. Ravnikar naj bi bil Kopitarjev simpatizer in nadaljevalec navedenih prizadevanj (Orožen 1996b: 21).

Breznikovo razmišljanje o jeziku prevodov in prevajalcev EiL je v veliki meri družbeno in ideološko pogojeno, kar se kaže v apriornem zavračanju tujega besedja v slovenskem jeziku in sklicevanju na tradicijo. Ločevanje med tujim in domačim je ena izmed jezikovnoideoloških' ${ }^{9}$ potez, poleg tega v citatih opazimo tudi jezikovnoideološko podmeno o tem, kako je potrebno jezik »očistiti, popraviti, izboljšati, dvigniti, iztrebiti (iz njega kaj), opraviti (kaj v njem) in osvoboditi ga.« Navedene vrednostne opredelitve implicitno izražajo še eno jezikovnoideološko tezo, namreč da jezik še ni dovolj razvit, kultiviran, da bi bil lahko opravljal vse tri vloge, ki jih pripisujemo jeziku - narodnozdruževalno, narodnopredstavniško in komunikacijsko.

\subsection{Kvantitativni rezulltati}

Breznik jezikovne spremembe med posameznimi izdajami EiL opredeljuje tudi z odstotki. Tako v njegovi razpravi beremo naslednje trditve:

- $\quad$ Dalmatin je pri novem zakonu svoje Biblie (1584) pridržal nad 60 \% Trubarjeve frazeologije, stilističnih in drugih posebnosti« (Breznik 1982: 28-29);

- $\quad$ Vsega skupaj ni popravil [Jurij Dalmatin - TT] nad 10 \% Trubarjevih germanizmov, v 90 \% pa mu je prijateljsko sledil« (Breznik 1982: 30);

- $\quad$ »Popravila so se le nekatera mesta [EiL 1787 - TT] (vsa še danes niso popravljena, kakor bomo videli), ki se ne ujemajo z vulgato, nekatere posamezne besede in nekateri izrazi, vse drugo (blizu 90 \%), je razen slovničnih oblik, Dalmatinovo« (Breznik 1982: 33);

- Vendar se tudi Japelj ni več kot približno za 50 \% osvobodil Dalmatina« (Breznik 1982: 33);

- $\quad$ Tudi v najnovejši ljubljanski in lavantinski izdaji (1912) imamo še 70-80 \% Burgarjevega besedila« (Breznik 1982: 33);

- $\quad$ Vsega skupaj je odpravil [Hren - TT] okrog 160-170 tujk, kar je za drobno knjižico jako veliko« (Breznik 1982: 36);

- $\quad$ Vse novotvorbe se mu niso enako posrečile [Hrenu - TT] in se zato niso vse udomačile. A večina se jih je ohranila do Pohlina in Japlja in še do Ravnikarja in Burgarja. Tretjina pa jih živi še danes v najnovejši ljubljanski in lavantinski izdaji (1912).« (Breznik 1982: 37)

Ob tako natančnih odstotnih navedbah podatkov se sprašujemo, kaj podatki pravzaprav pomenijo: ali predstavljajo delež slovenskega izrazja (čedalje bolj »slovensko lice« po Breznikovo), sprememb oz. odklonov od predloge svojega

9 Silverstein (po Petrović 2006: 44) definira jezikovno ideologijo kot »sistem verovanj o jeziku, ki ga oblikujejo govorci v cilju racionalizacije ali zagovarjanja načinov, kako sami doživljajo strukturo in rabo jezika«. Stabej njegovo definicijo dopolnjuje: »[G]otovo ne gre le za sistem predstav o posameznem jeziku, ampak o jezikih in medjezikovnih razmerjih v govorčevem jezikovnem repertoarju in v družbi« (Stabej 2012: 11). 
predhodnika ali kaj drugega. Breznik namreč ne v razpravi sami ne kje drugje ne opiše metode, na podlagi katere je prišel do takšnih zaključkov in tako natančnih izračunov. Mogoče je, da predstavljajo približno oceno, ki jo je Breznik podal na podlagi lastnega občutka. Njegov občutek je sicer temeljil na obsežni jezikovni in jezikoslovni izkušnji, toda še tako izbrušen občutek ne more nadomestiti razvidnega empiričnega postopka, saj empirično raziskovanje naj ne bi temeljilo zgolj na občutku, ampak naj bi vključevalo študij gradiva, zbranega in predstavljenega s pomočjo najbolj ustreznega instrumenta (npr. vsaj osnovni statistični podatki, seznam, preglednica z nakazanimi spremembami ipd.).

\section{3 Časovno opredeljevanje jezikovnih sprememb}

Breznikovo časovno opredeljevanje sem želela preveriti z lastno analizo in tako ugotoviti, kdaj je prišlo do sprememb, ki jih je v svoji razpravi navedel Breznik.

$\mathrm{V}$ preglednice sem izpisala vse primere spremenjenega besedja in tako sem $\mathrm{s}$ pomočjo tega raziskovalnega instrumenta lahko preverila, kdaj se je pojavila določena sprememba (vezana na določni člen, kazalni zaimek ob pridevniku določne oblike ali prislov ob glagolu) in ali se je besedje v spremenjeni obliki tudi ohranilo.

\subsection{1 Členi}

Opustitev določnega člena se pojavi: v dveh primerih leta 1809 (mrak te Ludy nozh ludftva in oroshje te luzhy - oroshje (vetlobe), v enem primeru že v letu 1672 (od Dauidovega fémena po tém méssej - od Dauidovega femena po méssej), v enem v letu 1787 (obeniga dolgá te Smèrti - nizh fmerti vrejdniga) ter v enem šele leta 1833 (je bil ta zhass dopolnjen - je pa prifhlo Jpolnjenje zhafa).10

Breznik omenja opuščanje kazalnega zaimka pri pridevnikih določne oblike v izdaji 1. 1803. V dveh primerih, od že prej v opombi omenjenih osmih, so opustili kazalni zaimek že 1. 1787 (ta préjdni viffehz párt-sagrinalu in téh mèrtvih jame - pokopalifha). Poleg tega ne gre samo za opuščanje, ampak tudi za zamenjavo leksema, kar dokazuje, da zgolj s preštevanjem in natančnim razčlenjevanjem jezikovnih sprememb izven konteksta tudi ne dobimo relavantnih podatkov in na njihovi podlagi ne moremo izpeljati tehtnih zaključkov.

\subsubsection{Kalkirane glagolske tvorjenke}

Po Brezniku naj bi bilo opuščanje prislovne sestavine znotraj kalkiranih glagolskih tvorjenk prvega tipa (po Merše 2009: 129) Ravnikarjeva inovacija, vendar sem v svoji analizi odkrila, da se v posameznih primerih pojavi že prej, in sicer v osmih primerih od vseh 46 . V nadaljevanju navajam vse primere primerjalno, tako da najprej navajam izhodiščno obliko11 in nato obliko, ko se prvič pojavi tvorjenka

10 Skupno sem našla in izpisala osem primerov z opuščanjem določnega člena. V oklepaju v paru navajam izhodiščno obliko besedila iz leta 1612 in obliko, pri kateri se prvič pojavi navedena sprememba.

11 Tako kot prej gre za prvo opazovano izdajo EiL iz leta 1612. 
brez prislovne sestavine (in se brez prislovne sestavine ohrani v vseh sledečih pregledanih izdajah): vsdignite gori - prizdignite glavé vaffe (̌̌e 1780); gori obudil - je obudil (že 1787); bèrft napréj poganjajo - berft poganjajo (že 1787); doli pokleknil - na kolęna poklęknil (1809); fe vkup isprafhovala - Je isprafhovala (že 1787); vún gonim Jkusi Beëlzebuba - de v'Beelzebubu hudizhe isgajnam (1777); hozhem jeft mrésho vùn vréjzhi - rafzprefztrém mre'so (1780); prozh prifhla od Templa - od tempelna perfhla (1777). V dveh primerih se je torej omenjena sprememba zgodila že v Pohlinovi izdaji iz leta 1777, v dveh primerih že v Küzmičevi izdaji iz leta 1780, v treh primerih v Japljevi iz leta 1787 in le v enem primeru v izdaji iz leta 1809.

Na podlagi rezultatov lahko posredno sklepamo, da so Breznikove formulacije bolj okvirne ocene trendov in tendenc, ki so jim sledili po Breznikovi presoji prireditelji besedil EiL pri svojem delu, kot pa natančni podatki na podlagi metodološko opravljene empirične analize.

Naši zaključki glede inovativnosti določenega jezikovnega pojava so seveda odvisni tudi od meril, ki vplivajo na odločitev, kaj je inovacija in inovativni postopek: ali jo/ga definiramo kot prvo pojavitev določene spremenjene oblike na splošno (ne glede na količino pojavitev) ali pa je inovativna izdaja tista, v kateri se prevladujoče uporablja določena inovacija ali inovativni postopek.

Ob razčlenjevanju sprememb kalkiranih glagolskih tvorjenk prvega tipa opazimo, da so se skozi različne izdaje EiL zgodile bolj kompleksne spremembe in ne zgolj opuščanje prislova.

Med opazovanimi 46 primeri lahko najdemo le sedem takih, pri katerih se je v zadnji izdaji iz leta 2003 pojavil glagol v isti izrazni podobi in zgolj z opuščenim prislovom, medtem ko pri 16 glagolih opazimo izrazne in pomenske spremembe ter spremembe v vezljivosti s posameznim predlogom (gl. preglednico 1).

Primeri, pri katerih se pojavi zgolj opustitev prislova: vsdignite gori vafhe glave (1612) - vzdignite glave (2003); gori obudil (1612) - je obudil (2003); gori fhàl (1612) - je šel (2003); gori poftaviti (1612) - postaviti (2003); v'fmili fe zhes me (1612) - usmili se (2003); doli pokleknil (1612) - je pokleknil (2003); hozhem jeft mrésho vùn vréjzhi (1612) - bom vrgel mreže (2003).12

Iz preglednice 1 je razvidno, da je skozi različne izdaje prišlo do različnih izraznih, pomenskih sprememb in sprememb v vezljivosti glagolov z določenim predlogom in posledično predmetom v določenem sklonu.

12 V zadnjem primeru se pojavi tudi sprememba glagolskega časa, poleg tega je glagol vreči, ki se $\mathrm{v}$ začetku nahaja $\mathrm{v}$ nedoločniku za naklonskim glagolom hoteti, $\mathrm{v}$ drugem primeru v prihodnjiku in brez naklonskega glagola.

13 V preglednico sem prepisala oblike samo v primeru, ko se besede ali besedne zveze kakor koli izrazno ali pomensko spreminjajo.

14 V prvem primeru se spremeni nanašalnica, ki je sprva Bog, nato leta 1833 luč in leta 2003 beseda.

15 Kos pečene ribe. 
Preglednica 1:13 Glagolske spremembe v EiL

\begin{tabular}{|c|c|c|c|c|c|c|c|c|c|c|}
\hline & 1612 & 1777 & 1780 & 1787 & 1809 & 1816 & 1833 & 1840 & 1912 & 2003 \\
\hline$\overline{1^{14}}$ & $\begin{array}{l}\text { ga néfo } \\
\text { gori vséli }\end{array}$ & & & & & & $\begin{array}{l}\text { njeni } \\
\text { je nifo } \\
\text { fprejéli }\end{array}$ & & & $\begin{array}{l}\text { je niso } \\
\text { sprejeli }\end{array}$ \\
\hline 2 & $\begin{array}{l}\text { Aku my } \\
\text { zhlovézh- } \\
\text { ku prizho- } \\
\text { vajne gori } \\
\text { vsamemo }\end{array}$ & & & & $\begin{array}{l}\text { Aku } \\
\text { zhlovęlhku } \\
\text { prizhova- } \\
\text { nje poter- } \\
\text { dimo }\end{array}$ & & $\begin{array}{l}\text { Ako } \\
\text { zhlovéfhko } \\
\text { pri- } \\
\text { zhevánje } \\
\text { fprejmemo }\end{array}$ & & & sprejmemo \\
\hline 3 & $\begin{array}{l}\text { bo gofpo- } \\
\text { doval zhes }\end{array}$ & & $\begin{array}{l}\text { bode } \\
\text { ravnao }\end{array}$ & ima vishati & & bo vodil & bo vladal & & & bo pasel \\
\hline 4 & $\begin{array}{l}\text { fo mèrmra- } \\
\text { li zhes }\end{array}$ & & $\begin{array}{l}\text { mrmrali } \\
\text { fzo prouti }\end{array}$ & $\begin{array}{l}\text { godernjali } \\
\text { zhes }\end{array}$ & & & $\begin{array}{l}\text { godernjáli } \\
\text { nad }\end{array}$ & & & $\begin{array}{l}\text { so godrnja- } \\
\text { li nad }\end{array}$ \\
\hline 5 & $\begin{array}{l}\text { gdu zhes } \\
\text { vass } \\
\text { vsdiguje }\end{array}$ & & & $\begin{array}{l}\text { fe povik- } \\
\text { huje }\end{array}$ & & & & & & $\begin{array}{l}\text { kdo dviga } \\
\text { nad vas }\end{array}$ \\
\hline 6 & $\begin{array}{l}\text { fe je pak } \\
\text { timu zhés } \\
\text { dal }\end{array}$ & & & & & $\begin{array}{l}\text { fe je temu } \\
\text { vdal }\end{array}$ & $\begin{array}{l}\text { fe mu je } \\
\text { vdal }\end{array}$ & & $\begin{array}{l}\text { Se je } \\
\text { uklonil } \\
\text { onemu }\end{array}$ & $\begin{array}{l}\text { (ampak) je } \\
\text { vse pre- } \\
\text { puščal / se } \\
\text { je izročal } \\
\text { njemu }\end{array}$ \\
\hline 7 & $\begin{array}{l}\text { fo ga } \\
\text { (Pontiu Pi- } \\
\text { latufhu De- } \\
\text { shelfkimu } \\
\text { Oblaftni- } \\
\text { ku) zhés } \\
\text { dali }\end{array}$ & & & & & & $\begin{array}{l}\text { in sdali } \\
\text { Ponzju } \\
\text { Pilatu, de- } \\
\text { shelnimu } \\
\text { poglavárju }\end{array}$ & $\begin{array}{l}\text { in isdali } \\
\text { Ponziju } \\
\text { Pilatusu, } \\
\text { poglavarju } \\
\text { deshele }\end{array}$ & & $\begin{array}{l}\text { Izročili } \\
\text { so ga }\end{array}$ \\
\hline 8 & $\begin{array}{l}\text { bèrft } \\
\text { napréj } \\
\text { poganjajo }\end{array}$ & & $\begin{array}{l}\text { gda } \\
\text { zpuscsáva } \\
\text { 'se z fzébe } \\
\text { lzád }\end{array}$ & $\begin{array}{l}\text { Kadar } \\
\text { vshę berft } \\
\text { poganjajo }\end{array}$ & & & & & & $\begin{array}{l}\text { začenjajo } \\
\text { brsteti }\end{array}$ \\
\hline 9 & 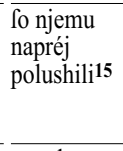 & & $\begin{array}{l}\text { oni fzo pa } \\
\text { prikázali } \\
\text { nyemi }\end{array}$ & $\begin{array}{l}\text { fo njemu } \\
\text { en kofs } \\
\text { pezhene } \\
\text { ribe } \\
\text { ponudili }\end{array}$ & $\begin{array}{l}\text { fo njemu } \\
\text { kofs } \\
\text { pezhene } \\
\text { ribe } \\
\text { ponujali }\end{array}$ & & & & & $\begin{array}{l}\text { Ponudili } \\
\text { so mu }\end{array}$ \\
\hline$\overline{10}$ & $\begin{array}{l}\text { vam bo } \\
\text { notèr dajal } \\
\text { vfe tu }\end{array}$ & & $\begin{array}{l}\text { i prináfao } \\
\text { de vám } \\
\text { na pamet } \\
\text { vfza }\end{array}$ & $\begin{array}{l}\text { inu vam bo } \\
\text { vfe noter } \\
\text { dál }\end{array}$ & & $\begin{array}{l}\text { inu vam bo } \\
\text { vfe dogo- } \\
\text { varjal }\end{array}$ & $\begin{array}{l}\text { in val bo } \\
\text { opomnil } \\
\text { vfiga }\end{array}$ & & $\begin{array}{l}\text { in vas bo } \\
\text { spomnil } \\
\text { vsega }\end{array}$ & $\begin{array}{l}\text { (bo) spom- } \\
\text { nil vsega }\end{array}$ \\
\hline$\overline{11}$ & $\begin{array}{l}\text { fe vkup } \\
\text { isprafho- } \\
\text { vala }\end{array}$ & $\begin{array}{l}\text { inu skupej } \\
\text { isprafhu- } \\
\text { vala }\end{array}$ & $\begin{array}{l}\text { i med } \\
\text { lzebom } \\
\text { fzpitávala }\end{array}$ & $\begin{array}{l}\text { inu fe } \\
\text { isprafho- } \\
\text { vala }\end{array}$ & & & & & & $\begin{array}{l}\text { razprav- } \\
\text { ljala }\end{array}$ \\
\hline$\overline{12}$ & $\begin{array}{l}\text { lim jeft } \\
\text { hótil vkup } \\
\text { lpraviti }\end{array}$ & & & & & & $\begin{array}{l}\text { lim hotel } \\
\text { sbrati tvoje } \\
\text { otròke }\end{array}$ & & & $\begin{array}{l}\text { sem hotel } \\
\text { zbrati }\end{array}$ \\
\hline$\overline{13}$ & $\begin{array}{l}\text { so bily } \\
\text { vkup } \\
\text { prifhli }\end{array}$ & & & & $\begin{array}{l}\text { Io vkùp } \\
\text { sbrani bily }\end{array}$ & & $\begin{array}{l}\text { fo fe bili } \\
\text { fofhli }\end{array}$ & & & $\begin{array}{l}\text { so bili } \\
\text { zbrani }\end{array}$ \\
\hline$\overline{14}$ & $\begin{array}{l}\text { je beféda } \\
\text { vunkaj lhla } \\
\text { méj Bratmi }\end{array}$ & & & $\begin{array}{l}\text { Leto } \\
\text { govorjenje } \\
\text { tedaj je } \\
\text { vunkaj } \\
\text { fhlu med } \\
\text { bratmi }\end{array}$ & & & $\begin{array}{l}\text { Rashlo fe } \\
\text { je govor- } \\
\text { jènje med }\end{array}$ & & $\begin{array}{l}\text { Sla je torej } \\
\text { govorica } \\
\text { med brate }\end{array}$ & $\begin{array}{l}\text { se je med } \\
\text { brati } \\
\text { razširila ta } \\
\text { govorica }\end{array}$ \\
\hline$\overline{15}$ & $\begin{array}{l}\text { vùn gonim } \\
\text { lkusi Beël- } \\
\text { zebuba }\end{array}$ & $\begin{array}{l}\text { de v' Beel- } \\
\text { zebubu } \\
\text { hudizhe } \\
\text { isgajnam }\end{array}$ & $\begin{array}{l}\text { ka jafz vu } \\
\text { Beelzebubi } \\
\text { zgányam } \\
\text { vragé }\end{array}$ & & & & & & & $\begin{array}{l}\mathrm{z} \text { Bélce- } \\
\text { bubom } \\
\text { izganjam } \\
\text { demone }\end{array}$ \\
\hline 16 & $\begin{array}{l}\text { néj prozh } \\
\text { prifhla od } \\
\text { Templa }\end{array}$ & $\begin{array}{l}\text { nigdar od } \\
\text { tempelna } \\
\text { perfhla }\end{array}$ & $\begin{array}{l}\text { ktera je nej } \\
\text { odfztoupila } \\
\text { od csérkvi }\end{array}$ & & $\begin{array}{l}\text { ona ny fhla } \\
\text { od Templa }\end{array}$ & & & & & $\begin{array}{l}\text { Templja ni } \\
\text { zapuščala }\end{array}$ \\
\hline
\end{tabular}


$\mathrm{V}$ dveh primerih se je v besedni zvezi z glagolom zamenjal le prislov: fo doli padli (1612) - fo prednj padli (2003) in fo vkup prifhli (1612) - sta prišla skupaj (2003).

Nekateri od teh glagolov pa so danes »predponski glagoli, pri katerih se v vlogi prve predpone oz. kot začetno besedotvorno obrazilo pojavlja prislovna sestavina, ki je prevodna ustreznica nemške predpone (prefiksa), ta pa je bodisi predložnega ali prislovnega izvora« (Merše 2009: 129). Takšnih je šest naslednjih primerov: je Jvoje oblazhilu doli polushil (1612) - je odložil (2003); on notèr pele (1612) - vpelje (2003); némate vkup sbirati na (1672) -Ne nabirajte si (2003); Pàhni vunkaj (1612) - Odpodi (2003); je fvoje oblazhilu doli polushil (1612) -je odložil vrhnje oblačilo (2003); notèr pele tiga pervorojeniga na (1612) - vpelje prvorojenca $v$ (2003).

\section{ZAKLJUČEK}

Breznikovo interpretacijo jezikovnih izrazil, vrednotenje avtorjev EiL in metodološki pristop, s katerim je prišel do svojih ugotovitev, je treba razumeti s predpostavko o zgodovinski, družbeno-ideološki določenosti njegovih in naših interpretacij, čeprav se jim skušamo vsaj eksplicitno in zavestno izogniti.

Navajanje eksaktnih podatkov brez gradiva, torej zgolj na podlagi približne ocene, v sodobnem jezikoslovju ni ustrezen postopek za prikazovanje raziskovalnih ugotovitev, vendar moramo pri vrednotenju pomena in vloge katerega koli jezikoslovca ali njegovega dela imeti pred očmi dejstvo, da se jezikoslovna znanost, njena epistemologija ali paradigma v času spreminja. Zanimiva bi bila raziskava, s katero bi proučili metodologijo slovenskih jezikoslovcev in jezikoslovne znanosti v različnih obdobjih. Natančneje bi pokazala dejavnike in smeri sprememb ideologije jezikoslovne znanosti.

Kljub temu da imamo v sodobnem času na voljo različne raziskovalne instrumente in smo obdani z najrazličnejšo moderno računalniško tehnologijo ter si lahko pomagamo s številnimi pridobitvami korpusnega jezikoslovja, se jezikoslovci razlikujemo v poudarkih, zornih kotih in teoretičnih pristopih k posameznim temam, od katerih so odvisni naši raziskovalni rezultati in zaključki.

Ob pregledu Breznikove bibliografije ne moremo mimo dejstva, da je v štiridesetih letih napisal sorazmerno obsežen opus (nad petdeset razprav in člankov, skoraj petdeset ocen in poročil ter štiri različice slovnice in več različic pravopisa, pri katerem je bil leta 1920 edini avtor, izdaje v tridesetih letih 20. stoletja pa je sestavil skupaj s Franom Ramovšem). Jezikoslovno delo je uspešno združeval z duhovniško, profesorsko in direktorsko službo. Njegovi spisi so izšli v treh knjigah izbranih spisov, in sicer v delih Jezik naših časnikarjev in pripovednikov (1944), Življenje besed (1976) in Jezikoslovne razprave (1982) (prim. Toporišič 1975). 
Njegove razprave so sprožale in še vedno sprožajo nova razmišljanja in raziskave, zato mu pripada ustrezno mesto v zgodovinskem spominu slovenskega jezikoslovja. Kot vsak jezikovni pristop in jezikoslovca v katerem koli zgodovinskem obdobju lahko tudi Breznikov jezikoslovni pristop razumemo samo znotraj jezikoslovnih teženj konkretnega družbenega obdobja, v katerem na jezikoslovno situacijo delujejo filozofske, družbeno-politične in druge silnice določenega obdobja, ki vplivajo tudi na znanstvene metode, na podlagi katerih poteka jezikoslovno raziskovanje. Tako Breznikova jezikoslovna teorija združuje različna znanstvena načela: na eni strani diahroni pristop k jeziku, ki poudarja pomen pismene tradicije, že uveljavljenih jezikovnih izrazil, prevajanje po črki oz. po grškem izvirniku, izločanje neizvirnih elementov jezika; po drugi strani pa v njegovi jezikoslovni misli najdemo tudi z današnjega stališča ideje, ki jih opredeljujemo kot sinhroni pristop k jeziku, kot so upoštevanje govorjenega in narečnega jezika ter upoštevanje posebne zgradbe in vloge umetnostnih del.

»[N]aloga slovničarja je, da kaže poti, katere so prave in dobre; hoditi po teh poteh pa mora vsak pisatelj sam, ne da bi slovničarji pisatelje nosili po njih; objektivna pravila sò, a žive zmeraj samo v osebnih oblikah pisateljev, zato je zmotno, da bi slovničarji in uredniki imeli v zakupu edino možno objektivno merilo ,pravilnega' jezika, na katero bi smeli napenjati in nategovati vse osebne oblike« (Šolar 1967: 54-55).

Na podlagi analize Breznikove razprave Literarna tradicija v Evangelijih in listih lahko zaključimo, da so jezikoslovnometodološka vprašanja pomembno področje jezikoslovnega raziskovanja, saj metodološka izhodišča poleg drugih raziskovalnih dejavnikov pomembno vplivajo na interpretacijo raziskovalnih spoznanj.

Ko si skušamo sodobni jezikoslovci ustvariti čim bolj objektivno sliko o pomenu in vlogi določenega jezikoslovca ter njegovega jezikoslovnega opusa in nazora, je pomembno, da poleg podrobnega proučevanja vsebine njegovih del v svoje raziskovanje vključimo tudi proučevanje znanstvenih pristopov, ki prevladujejo v obdobju, v katerem so nastala njegova dela, metodologijo in družbeni okvir, v katerem je prišel do svojih znanstvenih spoznanj.

$\mathrm{Na}$ podlagi razčlenitve Breznikove razprave lahko zaključimo, da je za relevantno zgodovinskojezikoslovno umestitev Breznika in njegovega jezikoslovnega opusa treba upoštevati tudi vpliv purističnega in ideološko obarvanega nazora o jeziku z nekaterimi v tej raziskavi posebej izpostavljenimi jezikovnoideološkimi potezami (npr. nadomeščanje germanizmov, jezikoslovci kot jezikoslovni vodniki); treba je razumeti filološko znanstveno metodo, t. i. historizem, in biti pozoren na vrednotenjsko opredeljevanje jezikovnih izrazil na njegovo raziskovanje, ko se skušamo približati duhu njegovega časa in stremimo k čim bolj avtentičnemu razumevanju Breznikovega pojmovanja jezikovnih sprememb. 


\section{VIRI}

Burgar 1833 = EiL 1833 = Jožef Burgar, LIŞTI in Evangelji v’ nedelje in prasnike [...], V' Ljubljani, 1833.

EiL $\mathbf{1 8 4 0}$ = Beríla ali Listi in EVANGELII v’ nedélje in prasnike [...], Na Dunaji, 1840.

EiL $2003=$ http://www.biblija.net/biblija.cgi?lang=sl

Hipolit $\mathbf{1 7 3 0}$ = EiL $\mathbf{1 7 3 0}$ = Hipolit Novomeški, EVANGELIA IN LYSTUVI: NA USE NEDELE INU Imenitne Prásnike [...], Labaci, M. DCC. XXX.

Hren 1612 = EiL 1612 = Tomaž Hren, EVANGELIA INV LYSTVVI: Na vfe Nedele, inu [...], Laibach, M. DC. XII.

Japelj 1787 = EiL 1787 = Jurij Japelj, LYSTI INU EVANGELIA, NA VSE NEDELE, INU PRASNIKE [...], V' Lublani, 1787

Japelj $\mathbf{1 8 0 9}$ = EiL 1809 = Jurij Japelj, LISTI INU EVANGELJI, NA USE NEDELE [...], V' LUBLANI, 1809

Küzmič $\mathbf{1 7 8 0}=\mathbf{K M} \mathbf{1 7 8 0}=$ Mikloš Küzmič, Szvéti Evangyeliomi Pouleg Kalendárioma, [...] na Sztári Szlovenszki Jezik, Po [...] Küzmics Miklósi, [...] Obrnyeni [...], V-Soproni, 1780.

Lesar 1912 = EiL 1912 = Jožef Lesar, Berila in evangeliji za nedelje, praznike in imenitnejšse godove cerkvenega leta, priredil Jožef Lesar, Ljubljana, 1912.

Pohlin 1777 = EiL 1777 = Marko Pohlin, BRANJA, INU EVANGELIUMI, NA NEDELE, INU PRASNEKE ZHES ZELU LEJTU, IS LATINSKIGA NA KRAYNSKI JESIK SVESTU, INU SKERBNU PRESTAVLENE, POPRAVLENE, INU POGMIRANE [...], V' LUBLANI, 1777.

Ravnikar 1816 = EiL 1816 = Matevž Ravnikar, BERILA, LISTI, in EVANGELJI v' Nedele in godove zeliga léta [...], V' Lublani, 1816.

Schönleben 1672 = EiL 1672 = Janez Schönleben, EVANGELIA INU LYSTUVI: NA V'SE NEDELE INU Jmęnitne Prasnike [...], v' Nemfkim Gradzu, M. DC. LXXII.

\section{LITERATURA}

Ahačič $\mathbf{2 0 0 9}$ = Kozma Ahačič, Pregled jezikoslovnih zapisov o slovenščini v neslovničnih knjižnih in rokopisnih delih 1672-1758 I: Schönleben, Kastelec, Valvasor, Svetokriški, Vorenc, Hipolit, Slavistična revija 57 (2009), št. 4, 563-602.

Bajec 1965 = Anton Bajec, Kako smo Slovenci čistili svoj jezik, v: Jezikovni pogovori [1], ur. France Vurnik, Ljubljana: Cankarjeva založba, 1965, 203-208.

Bernard 2002 = Antonija Bernard, Slovenščina pri francoskih jezikoslovcih (ali: med historizmom in strukturalizmom), v: Historizem v raziskovanju slovenskega jezika, literature in kulture, ur. Aleksandra Derganc, Ljubljana: Filozofska fakulteta, Oddelek za slovanske jezike in književnosti, 2012 (Obdobja 18), 3-12.

Bezlaj 2003 = France Bezlaj, Blišč in beda slovenskega jezika, v: France Bezlaj, Zbrani jezikoslovni spisi II, ur. Metka Furlan, Ljubljana: Založba ZRC, ZRC SAZU, 2003 (Linguistica et philologica 6/II), 751-787.

Breznik $1917=$ Anton Breznik, Literarna tradicija $\vee »$ Evangelijih in listih «, Dom in svet 30 (1917), 170-174, 225-230, 279-284, 333-347. - Ponatis v: Breznik 1982: 27-54.

Breznik 1967 = Anton Breznik, Življenje besed, priredil Jakob Šolar, Maribor: Obzorja, 1967 (Glotta 7).

Breznik 1982 = Anton Breznik, Jezikoslovne razprave, izbral in uredil Jože Toporišič, Ljubljana: Slovenska matica, 1982.

Dular 1988 = Janez Dular, Med jezikovno politiko in jezikovno kulturo, v: Seminar slovenskega jezika, literature in kulture: zbornik predavanj 24, ur. Breda Pogorelec, Ljubljana: Filozofska fakulteta, 1988, 31-47.

Kalin Golob 2008 = Monika Kalin Golob, Jezikovnokulturni pristop h knjižni slovenščini, Ljubljana: Fakulteta za družbene vede, 2008.

Kurinčič 2002 = Jože Kurinčič, Anton Breznik, jezikoslovec za vse čase, Slovenščina v šoli 7 (2002), št. $1,9-13$. 
Mathesius 1932 = Vilém Mathesius, O požadavku stability ve spisovném jazyce, v: Spisovná čeština a jazyková kultura [1], ur. Bohuslav Havránek - Miloš Weingart, Praha: Melantrich, 1932, 14-31.

Merše 1988 = Majda Merše, Besedotvorni pomeni izsamostalniških glagolov v Dalmatinovi Bibliji, Slavistična revija 36 (1988), št. 4, 375-397.

Merše 2009 = Majda Merše, Slovenski knjižni jezik 16. stoletja: razprave o oblikoslovju, besedotvorju, glasoslovju in pravopisu, Ljubljana: Založba ZRC, ZRC SAZU, 2009 (Linguistica et philologica 23).

Orel 2002 = Irena Orel, Historizem v sinhronih oblikoslovnih opisih 19. in 20. stoletja, v: Historizem $v$ raziskovanju slovenskega jezika, literature in kulture, ur. Aleksandra Derganc, Ljubljana: Filozofska fakulteta, Oddelek za slovanske jezike in književnosti, 2002 (Obdobja 18), 201-217.

Orožen 1996a = Martina Orožen, Kopitar kot pobudnik skladenjske in besedijske preobrazbe, v: Kopitarjev zbornik, ur. Jože Toporišič, Ljubljana: Filozofska fakulteta, Oddelek za slovanske jezike in književnost, 1996 (Obdobja 15), 79-92.

Orožen 1996b = Martina Orožen, Oblikovanje enotnega slovenskega knjižnega jezika v 19. stoletju, Ljubljana: Filozofska fakulteta, Znanstveni inštitut Filozofske fakultete, 1996.

Orožen 2002 = Martina Orožen, Odkrivanje strukturne identitete slovenskega jezika v luči raziskovalnih metod 19. stoletja, v: Historizem v raziskovanju slovenskega jezika, literature in kulture, ur. Aleksandra Derganc, Ljubljana: Filozofska fakulteta, Oddelek za slovanske jezike in književnosti, 2002 (Obdobja 18), 219-232.

Ožbolt 2006 = Martina Ožbolt, Prevajalske strategije in vprašanja koherence ob slovenskih prevodih Machiavellijevega Vladarja, Ljubljana: Slavistično društvo Slovenije, 2006 (Slavistična knjižnica 10).

Pogorelec 1962 = Breda Pogorelec, Breda Pogorelec o novem pravopisu 1962, Naši razgledi 11 (1962), št. 21, 158-166.

Pogorelec 1963 = Breda Pogorelec, Slovenski pravopis 1962, Problemi I 1963, 167-183.

Pogorelec 2011 = Breda Pogorelec, Zgodovina slovenskega knjižnega jezika, Ljubljana: Založba ZRC, ZRC SAZU, 2011.

Skubic 1997/98 = Darja Skubic, Primerjava razprave A. Breznika Besedni red v govoru (1908) s poglavjem Coherence v delu T. A. van Dijka Text and Coherence (1976), Jezik in slovstvo 43 (1997/98), št. 6, 269-286.

Skubic 2005 = Andrej Ermenc Skubic, Obrazi jezika, Ljubljana: Študentska založba, 2005.

SSKJ = Slovar slovenskega knjižnega jezika, Ljubljana: Založba ZRC, ZRC SAZU - Inštitut za slovenski jezik Frana Ramovša, 1995.

Stabej 1998 = Marko Stabej, Oblikovanje knjižnega jezika v 19. st. med narodno enotnostjo in socialno razločevalnostjo, v: Seminar slovenskega jezika, literature in kulture 34, ur. Erika Kržišnik, Ljubljana: Filozofska fakulteta, Oddelek za slovanske jezike in književnosti, 1998, 19-33.

Stabej $\mathbf{2 0 1 0}$ = Marko Stabej, V družbi z jezikom, Ljubljana: Trojina, zavod za uporabno slovenistiko, 2010 (Trojinski konj).

Stabej 2012 = Marko Stabej, Jezik, nazori in nadzor, v: Seminar slovenskega jezika, literature in kulture 48: ideologije v slovenskem jeziku, literaturi in kulturi, ur. Aleksander Bjelčevič, Ljubljana: Filozofska fakulteta, Oddelek za slovenistiko, 2012, 11-20.

Škrabec 1994-1998 = Stanislav Škrabec, Jezikoslovna dela 1-4, ur. Jože Toporišič, Nova Gorica: Frančiškanski samostan Kostanjevica, 1994-1998.

Šolar 1967 = Jakob Šolar, Anton Breznik, v: Anton Breznik, Življenje besed, Maribor: Obzorja, 1967 (Glotta 7), 7-74.

Thomas 1997 = George Thomas, The Impact of Purism on the Development of the Slovene Standard Language, Slovenski jezik - Slovene Linguistic Studies (Ljubljana - Lawrence), št. 1 (1997), $133-152$.

Toporišič 1975 = Jože Toporišič, Beseda o Brezniku, Jezik in slovstvo 20 (1974/75), št. 4, 99-102.

Toporišič 1982 = Jože Toporišič, Nova slovenska skladnja, Ljubljana: DZS, 1982.

Toporišič 1995a = Jože Toporišič, Besedilna skladnja, Slavistična revija 43 (1995), št. 1, 13-21.

Toporišič 1995b = Jože Toporišič, Besedjeslovne razprave, Ljubljana: Založba ZRC, ZRC SAZU, 1995. 
Urbančič 1963 = Boris Urbančič, Ob novem slovenskem pravopisu, Slavistična revija 14 (1963), 211-228.

Vacek 1966 = Jaroslav Vacek, Linguistic School of Prague, Bloomington - London: Indiana University Press, 1966.

Vidovič Muha 1994 = Ada Vidovič Muha, Evropska razsežnost Breznikovega pojmovanja »govornega odstavka«, v: Zbornik Slavističnega društva Slovenije 4: zborovanje slavistov, Celje, 1993, Ljubljana: Zavod Republike Slovenije za šolstvo in šport, 1994, 39-46.

Vidovič Muha $\mathbf{2 0 0 0}$ = Ada Vidovič Muha, Prague funcional stratification of language in Slovene linguistic, Slovo a slovesnost 61 (2000), št. 4, 276-283.

Vidovič Muha 2006 = Ada Vidovič Muha, Breznikova napoved jezikoslovne teme 20. stoletja - praška teorija členitve po aktualnosti (ob Škrabčevi oceni Breznikovega reda v govoru), v: Zbornik Škrabčeva misel V: zborniks simpozija 2005: jezikoslovci in njihova dela v Škrabčevih očeh, ur. Jože Toporišič, Nova Gorica: Frančiškanski samostan Kostanjevica, 2006, 127-135.

Vidovič Muha 2008 = Ada Vidovič Muha, Breznik - predhodnik praške teorije členitve po aktualnosti, v: Jezikovna prepletanja, ur. Monika Kalin Golob - Nataša Logar - Anton Grizold, Ljubljana: Fakulteta za družbene vede, 2008 (Stičišča), 35-53.

Zuljan Kumar 2008 = Danila Zuljan Kumar, Besedni red v govorjenih slovenskih narečjih, v: Zbornik Škrabčeva misel VI: zbornik s simpozija 2007, ur. Jože Toporišič, Nova Gorica: Frančiškanski samostan Kostanjevica, 2008, 121-135.

\section{SUMMARY}

\section{Anton Breznik's conceptualization of linguistic changes in Evangeliji in listi (Gospels and Epistles)}

This article uses a research methodology to analyze Anton Breznik's commentary on the literary tradition in the collection known as Evangeliji in listi (EiL, Gospels and Epistles). The article starts by analyzing Breznik's interpretation of the concept of literary tradition and some of his statements about the development of standard Slovenian, and literary style in EiL is also examined. It is then observed how linguistic ideology affects Breznik's definitions and the judgement of various authors in EiL. Quantitative data analysis and the definition of the meaning and the time of a linguistic innovation is also examined. Finally, changes in various verb-adverb combinations in eleven editions of EiL (from 1612 to 2003) are examined. 